\title{
28. MAGNETIC PROPERTIES OF BASALTS FROM THE GALAPAGOS SPREADING CENTER: A CORRELATION BETWEEN BASALTS FROM THE GALAPAGOS RIFT AND THE COSTA RICA RIFT ${ }^{1}$
}

\author{
Toshio Furuta, Ocean Research Institute, University of Tokyo, Tokyo 164, Japan
}

\section{INTRODUCTION}

Measurement of the magnetic properties of basalts from the area of the Galapagos Spreading Center by both surface and deep-tow techniques provides information regarding large-amplitude linear magnetic anomalies. In this chapter are reported the results of such measurements and correlations with data from the Costa Rica Rift.

Studies of basement rocks dredged from the Galapagos area have shown that those nearest the Spreading Center have a much higher intensity of magnetization than do other basement rocks (Anderson et al., 1975). Basalts from the ridge crest with normal amplitude anomalies contain $9 \%$ total iron, while those from the ridge crest with large amplitude anomalies contain $14 \%$ total iron. Titanomagnetite enrichment in basalts could cause the observed large amplitudes (Vogt and Johnson, 1973; Anderson et al., 1975).

\section{SAMPLE SITES}

Drilling sites on Deep Sea Drilling Project (DSDP) Leg 70 were located approximately $17 \mathrm{~km}$ south of the Galapagos Rift Zone (Fig. 1). Basement rocks for magnetic study were recovered from four sites located at anomalous geothermal areas; Sites 506 and 507 are located in a high heat-flow area; Site 508 is in a low heatflow area; and Site 510 is in a normal heat-flow area (Becker et al., this volume). Ages of basement rocks at these sites are estimated by magnetic anomaly patterns as follows: Site 506, 0.54 m.y.; Site 507, 0.69 m.y.; Site 508, 0.85 m.y.; and Site 510, 2.73 m.y. Two other sites are included for magnetic correlation with this area. Sites 504 and 505 of DSDP Leg 69 were located at the south flank of the Costa Rica Rift; crustal ages at these sites are estimated at 3.9 m.y. and $6.2 \mathrm{~m} . \mathrm{y}$., respectively (Langseth et al., in press) (Fig. 1). The experimental procedures used for this study are the same as those described in Furuta (in press).

\section{RESULTS}

\section{Saturation Magnetization and Saturation Remanent Magnetization}

Results are shown in Table 1. The average value of saturation magnetization $\left(J_{s}\right)$ from anomalous heat-

\footnotetext{
${ }^{1}$ Honnorez, J., Von Herzen, R. P., et al., Init. Repts. DSDP, 70: Washington (U.S. Govt. Printing Office).
}

flow areas (Holes 506G, 507B, and 508B) is around 1 $\mathrm{emu} / \mathrm{g}$, whereas that from the normal heat-flow area (Hole 510) is less than $0.6 \mathrm{emu} / \mathrm{g}$. In this case, it appears that saturation magnetization depends primarily on the concentration of ferromagnetic minerals and not on progressive alteration. The wide range of saturation magnetization suggests a highly variable concentration of ferromagnetic minerals in each basalt, though produced at the same spreading center. The mean values of saturation magnetization for each hole are of particular interest: Hole 507B samples have the highest $J_{s}$ value ( $>1.4$ $\mathrm{emu} / \mathrm{g}$ ) whereas Hole 510 samples show a wide range of $J_{s}$ values $(0.15-0.82 \mathrm{emu} / \mathrm{g})$ and their mean is the lowest value of $J_{s}(0.534 \mathrm{emu} / \mathrm{g})$.

Saturation remanent magnetization $\left(J_{r s}\right)$ values range from $0.07 \mathrm{emu} / \mathrm{g}$ to $0.6 \mathrm{emu} / \mathrm{g}$. The value for Hole 507B is quite small in spite of a high $J_{s}$.

Coercive Force $\left(H_{c}\right)$ and Remanent Coercive Force $\left(H_{r c}\right)$

Individual values of coercive force and remanent coercive force vary considerably for each hole, ranging from $45 \mathrm{Oe}$ to $230 \mathrm{Oe}$ and from $105 \mathrm{Oe}$ to $310 \mathrm{Oe}$, respectively. As shown in Table 1, samples having low $H_{c}$ ( $<100 \mathrm{Oe}$ ) show relatively high $J_{s}$. The ratio of $H_{r c} / H_{c}$ has been used as an indicator of magnetic grain size. Day et al. (1977) showed that for stoichiometric titanomagnetite $\left[\mathrm{xFe}_{2} \mathrm{TiO}_{4}(1-\mathrm{x}) \mathrm{Fe}_{3} \mathrm{O}_{4}\right]$ with $\mathrm{x}=0.6$, one obtains $H_{c} / H_{r c}<4$ for pseudo-single or single domain particles $(30-40 \mu \mathrm{m})$. For the present samples, $H_{c} / H_{r c}<3$, suggesting that their predominant grain sizes are pseudosingle or single domain.

\section{Thermomagnetic Analysis and Curie Temperatures}

Thermomagnetic curves of samples from Holes 506G, 507B, 507C, 508B, and 510 can be classified into three types as shown in Figure 2. Results of the thermomagnetic analysis are summarized in Table 2 . Curie temperatures of reversible samples (Type I), which may represent the original phase or a slightly oxidized phase of titanomagnetites in basalts, range from $130^{\circ} \mathrm{C}$ to $300^{\circ} \mathrm{C}$. The frequency of occurrence of reversible types in each hole is more than $50 \%$. It suggested that the titanomagnetites in these samples are not always oxidized at low temperatures. Curie temperatures of irreversible samples (Type II), which are thought to represent the oxidized phase of the original titanomagnetites, range from $180^{\circ} \mathrm{C}$ to $300^{\circ} \mathrm{C}$. These Curie temperatures, however, have relatively lower values than those of oxidized titanomagnetites which are often observed in submarine basalts. The irreversible thermomagnetic curves of Type 


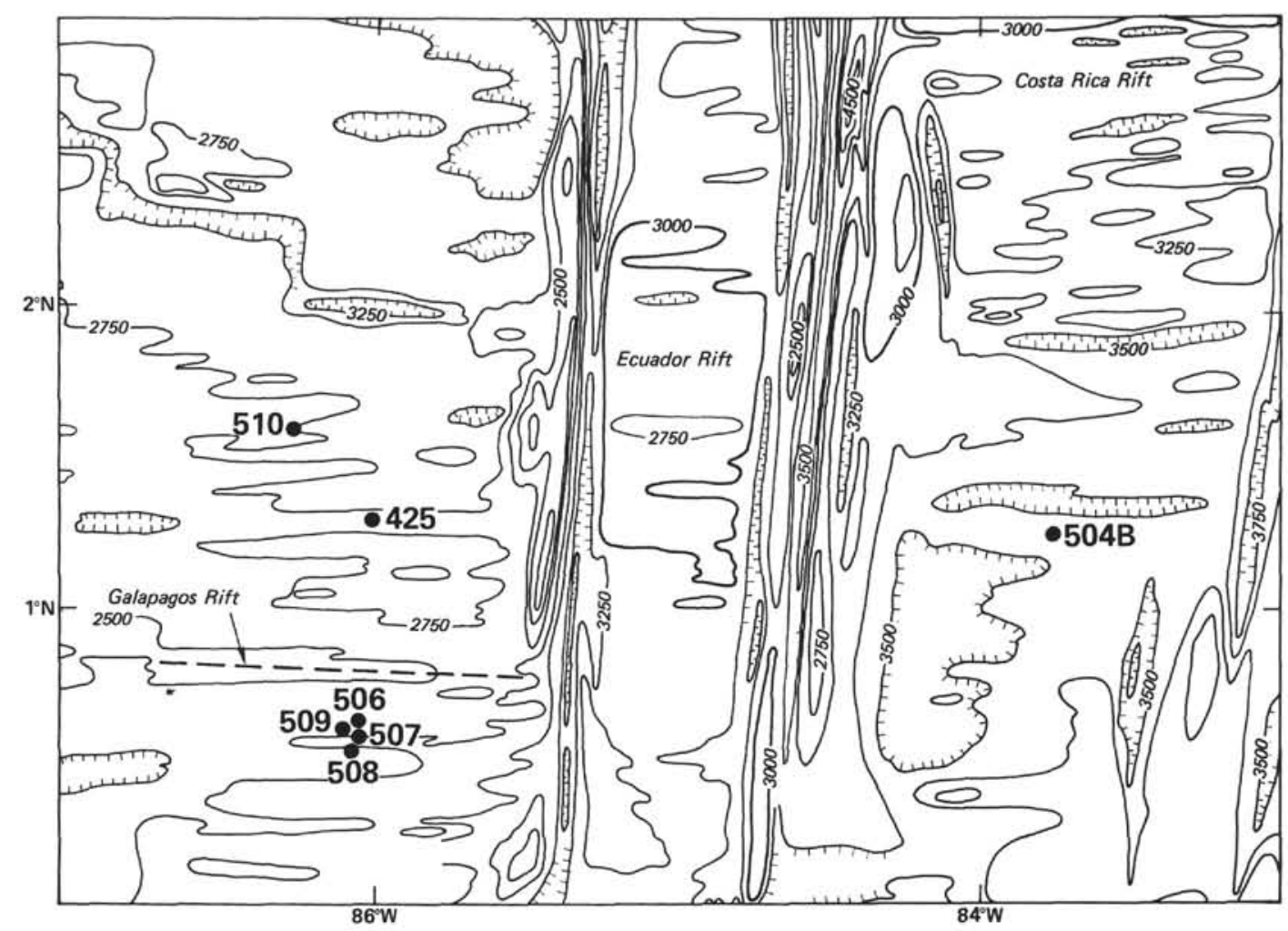

Figure 1. Location of Legs 69 and 70, Sites 504 through 510.

III are rarely observed in submarine basalts; this type was found in only one sample.

\section{Chemical Properties of Titanomagnetite}

The grain size of titanomagnetites in the present samples is relatively small, so that chemical analysis using an electron microprobe could be done on only a few samples. The ratio of $\mathrm{Ti} / \mathrm{Fe}$ was obtained, and the $\mathrm{x}$-value of the ulvospinel-magnetite solid solution $\left[\mathrm{xFe}_{2} \mathrm{TiO}_{4}\right.$. $(1-\mathrm{x}) \mathrm{Fe}_{3} \mathrm{O}_{4}$ ] or its oxidized product was calculated on the assumption of stoichiometric ulvospinel-magnetite series. Results are shown in Table 2. The $\mathrm{x}$-value of Hole 507B samples is higher than those of normal submarine basalts, ranging from 0.65 to 0.70 .

The higher $\mathrm{x}$-value (higher titanium content) for titanomagnetite could be explained as migration of iron ions from the original titanomagnetite phase, accompanying oxidization at low temperatures (Ryall and Hall, 1980). However, the low Curie points of most samples from Hole 507B preclude significant oxidation at low temperatures in spite of a high $\mathrm{x}$-value.

The $\mathrm{x}$-value of samples from Hole 510 is lower than that of samples from Hole 507B, showing a normal value of $x=0.6$ (Sample 510-10-1, 26-28 cm). Sample $510-11-1,96-100 \mathrm{~cm}$ shows a wide range in values (i.e., 0.23-0.69), as shown in Figure 3.

\section{DISCUSSION}

Some basalts from the area of the Galapagos Spreading Center are known to have a higher total iron oxide content than do normal tholeiitic basalts (Anderson et al., 1975; Hekinian et al., 1978). The high saturation magnetization $\left(J_{s}\right)$ of Holes 506G, 507B, and 508B suggests that the content of magnetic minerals is high. Data from Sites 424 and 425 , which are located on an area of high heat flow, show high $J_{s}$ (Petersen and Roggenthen, 1980 ). On the other hand, the $J_{s}$ of samples from Hole 510 , which was located on an area of normal heat flow, has a wide range and a lower mean $J_{s}$ value, suggesting one of the following: (1) that the content of magnetic minerals is very similar to that of the high $J_{S}$ holes. but that weathering has decreased the $J_{s}$ values or (2) that the concentration of magnetic minerals is normal and similar in content to that of other submarine basalts. Unfortunately, data for total iron oxide content have not yet been obtained.

It is apparent that titanomagnetites in more than half the samples do not show any sign of oxidation at low temperatures in spite of the high degree of hydrothermal circulation at Holes 506G, 507B, and 508B (Karato, this volume). Thus, low temperature oxidation of titanomagnetite is not always accelerated by hydrothermal circulation.

It is well known that the $\mathrm{x}$-value of titanomagnetite in submarine basalts has limited variation and that it is about 0.6 (e.g., Johnson and Hall, 1978; Ryall and Hall, 1980; Petersen and Roggenthen, 1980). Although there are not enough samples to discuss the $\mathrm{x}$-value of titanomagnetite, some data do show a different value from normal submarine basalts. The $\mathrm{x}$-value of samples from Hole $507 \mathrm{~B}$ is 0.65 to 0.70 , which is considerably higher than that of nonoxidized titanomagnetite in normal basalts. Samples 506G-2-1, 9-11 cm and 510-10-1, 12-14 $\mathrm{cm}$ show a normal value around 0.6. Sample 510-11- 
Table 1. Magnetic properties of basalts from Holes 506B, 507B, $507 \mathrm{C}, 508 \mathrm{~B}$, and 510 .

\begin{tabular}{|c|c|c|c|c|c|c|}
\hline $\begin{array}{c}\text { Samples } \\
\text { (intervals in cm) }\end{array}$ & $J_{S}$ & $J_{r s}$ & $J_{r S} / J_{S}$ & $H_{c}$ & $H_{r c}$ & $H_{r c} / H_{c}$ \\
\hline \multicolumn{7}{|l|}{ Hole $506 \mathrm{G}$} \\
\hline $\begin{array}{l}2-1,9-11 \\
2-1,75-77 \\
2-1,86-88 \\
2-1,122-127 \\
\text { hole mean }\end{array}$ & $\begin{array}{l}0.928 \\
0.886 \\
1.065 \\
0.820 \\
0.925\end{array}$ & $\begin{array}{l}0.243 \\
0.550 \\
0.274 \\
0.307 \\
0.344\end{array}$ & $\begin{array}{l}0.262 \\
0.621 \\
0.257 \\
0.374 \\
0.380\end{array}$ & $\begin{array}{r}88 \\
152 \\
53 \\
163 \\
114\end{array}$ & $\begin{array}{l}140 \\
240 \\
108 \\
265 \\
188\end{array}$ & $\begin{array}{l}1.59 \\
1.58 \\
2.04 \\
1.63 \\
1.71\end{array}$ \\
\hline \multicolumn{7}{|l|}{ Hole 507B } \\
\hline $\begin{array}{l}1-1,18-20 \\
1-1,20-22 \\
1-1,42-44 \\
1-1,57-59 \\
\text { hole mean }\end{array}$ & $\begin{array}{l}1.324 \\
1.646 \\
1.296 \\
1.326 \\
1.398\end{array}$ & $\begin{array}{l}0.253 \\
0.261 \\
0.279 \\
0.248 \\
0.260\end{array}$ & $\begin{array}{l}0.191 \\
0.159 \\
0.215 \\
0.187 \\
0.188\end{array}$ & $\begin{array}{l}45 \\
69 \\
98 \\
66 \\
70\end{array}$ & $\begin{array}{l}105 \\
128 \\
165 \\
110 \\
134\end{array}$ & $\begin{array}{l}2.33 \\
1.86 \\
1.68 \\
1.67 \\
1.88\end{array}$ \\
\hline \multicolumn{7}{|l|}{ Hole $507 \mathrm{C}$} \\
\hline $\begin{array}{l}\text { B1-1, 5-7 } \\
3-1,40-43 \\
\text { hole mean }\end{array}$ & $\begin{array}{l}0.749 \\
0.778 \\
0.763\end{array}$ & $\begin{array}{l}0.418 \\
0.561 \\
0.489\end{array}$ & $\begin{array}{l}0.558 \\
0.593 \\
0.575\end{array}$ & $\begin{array}{l}142 \\
152 \\
146\end{array}$ & $\begin{array}{l}196 \\
280 \\
238\end{array}$ & $\begin{array}{l}1.38 \\
1.84 \\
1.61\end{array}$ \\
\hline \multicolumn{7}{|l|}{ Hole 508B } \\
\hline $\begin{array}{l}3-1,11-13 \\
3-1,42-44 \\
4-1,3-5 \\
\text { hole mean }\end{array}$ & $\begin{array}{l}0.853 \\
0.956 \\
0.886 \\
0.898\end{array}$ & $\begin{array}{l}0.499 \\
0.394 \\
0.524 \\
0.472\end{array}$ & $\begin{array}{l}0.585 \\
0.412 \\
0.591 \\
0.529\end{array}$ & $\begin{array}{l}230 \\
157 \\
160 \\
182\end{array}$ & $\begin{array}{l}310 \\
205 \\
300 \\
272\end{array}$ & $\begin{array}{l}1.35 \\
1.31 \\
1.87 \\
1.51\end{array}$ \\
\hline \multicolumn{7}{|l|}{ Hole 510} \\
\hline $\begin{array}{l}8-2,100-102 \\
8-2,116-118 \\
9-1,31-33 \\
9-1,56-58 \\
9-1,82-84 \\
9-2,6-8 \\
9-2,133-134 \\
9-3,26-28 \\
9-3,34-36 \\
10-1,12-14 \\
10-1,26-28 \\
11-1,18-20 \\
11-1,96-100 \\
\text { hole mean }\end{array}$ & $\begin{array}{l}0.483 \\
0.524 \\
0.667 \\
0.780 \\
0.792 \\
0.609 \\
0.341 \\
0.510 \\
0.244 \\
0.822 \\
0.660 \\
0.353 \\
0.154 \\
0.534\end{array}$ & $\begin{array}{l}0.158 \\
0.170 \\
0.147 \\
0.172 \\
0.210 \\
0.146 \\
0.160 \\
0.168 \\
0.133 \\
0.244 \\
0.138 \\
0.137 \\
0.066 \\
0.158\end{array}$ & $\begin{array}{l}0.327 \\
0.324 \\
0.220 \\
0.221 \\
0.265 \\
0.240 \\
0.469 \\
0.329 \\
0.545 \\
0.297 \\
0.209 \\
0.388 \\
0.429 \\
0.336\end{array}$ & $\begin{array}{r}118 \\
157 \\
78 \\
64 \\
88 \\
86 \\
170 \\
112 \\
148 \\
136 \\
79 \\
156 \\
179 \\
121\end{array}$ & $\begin{array}{l}195 \\
244 \\
140 \\
165 \\
155 \\
165 \\
265 \\
184 \\
205 \\
215 \\
142 \\
250 \\
285 \\
201\end{array}$ & $\begin{array}{l}1.65 \\
1.55 \\
1.79 \\
2.66 \\
1.76 \\
1.92 \\
1.56 \\
1.64 \\
1.38 \\
1.58 \\
1.80 \\
1.60 \\
1.59 \\
1.73\end{array}$ \\
\hline
\end{tabular}

Note: $J_{S}=$ saturation magnetization; $J_{r S}=$ saturation remanence magnetization; $H_{c}=$ coercive force; $H_{r c}=$ remanence coercive force.

$1,96-100 \mathrm{~cm}$ shows wide variation in $\mathrm{x}$-values, ranging from 0.23 to 0.70 .

Figure 3 shows the variation of $\mathrm{x}$-values with $\mathrm{Al}_{2} \mathrm{O}_{3}$ content for titanomagnetites in four samples. Three of these-Samples 506G-2-1, 9-11 cm, 507B-1-1, 18-20 $\mathrm{cm}$, and 507B-1-1, 57-59 cm-show a narrow range of $\mathrm{x}$-values, whereas Sample 510-11-1, 96-100 cm shows a wide variation of values.

Similar wide variation of $\mathrm{x}$-values is found in the Costa Rica Rift basalts (Furuta, 1980). The relationship between $\mathrm{x}$-values (or $\mathrm{Ti} / \mathrm{Fe}$ atomic ratio) and $\mathrm{Al}_{2} \mathrm{O}_{3}$ content shows a rough correlation: $\mathrm{x}$-values increase (i.e., Ti content increases) as $\mathrm{Al}_{2} \mathrm{O}_{3}$ content decreases. This indicates that the crystallization stage of titanomagnetite may be different and that the earlier crystallized titanomagnetite contains a higher $\mathrm{Al}_{2} \mathrm{O}_{3}$ content (Fig. 3).
Finally, it is interesting to compare the magnetic properties between basalts from the Galapagos Rift and the Costa Rica Rift. In Figure 4, the saturation magnetization $\left(J_{s}\right)$ as determined on Legs 54,69 , and 70 on anomalous heat-flow areas is plotted against crustal age. It is observed that $J_{s}$ decreases with age. This correlation may suggest that titanomagnetite was progressively oxidized with increasing crustal age. However, at four sites whose ages are within one m.y., $J_{s}$ varies from 0.9 to $1.4 \mathrm{emu} / \mathrm{g}$. This variation may be attributed to titanomagnetite content rather than to low temperature oxidation. $J_{s}$ at Site 505 is smaller than at Site 504 despite younger age and less oxidation. This discrepancy may explain why the content of titanomagnetite at Site 504 should be somewhat larger than at Site 505. Variation in iron-oxide content in the bulk chemistry of basalts from Sites 504 and 505 is small but distinct. The chemical composition of these samples supports the assumption of a difference in titanomagnetite content between Sites 504 and 505 . Hole 424 basalts contain 14\% total iron oxide (Hekinian et al., 1978), whereas Hole 504 basalts have a normal total iron oxide content with values around 10\% (Marsh and Tarney, in press).

Figure 5 shows the Curie temperatures of samples from Legs 54, 69, and 70 plotted against crustal age. It is clear that Curie temperature shows a distinct increase with age. The increase in Curie temperature from that of the initial phase of titanomagnetite crystallization is known to result from oxidization at low temperatures. Figure 5 suggests that a great deal of low temperature oxidation of titanomagnetites might be accomplished within a few million years. This is consistent with the data of Johnson and Atwater (1977), who reported results from the FAMOUS investigations showing that as the distance from the ridge axis (or crustal age) increases, the Curie temperature increases to values around $300^{\circ} \mathrm{C}$. They attributed these increases in Curie temperature to progressive low temperature oxidation of the initial titanomagnetite to titanomaghemite. In fact, most samples from Hole 504, a high heat-flow area, were oxidized at low temperature, but more than half the samples from Hole 505B were not oxidized (Furuta, in press). It thus appears that low temperature oxidation of titanomagnetite may not always depend upon increasing age, but rather on grain size or preservation. This result is consistent with previous studies of submarine basalts. Especially in a hydrothermally active area, the microstructure surrounding the titanomagnetites may control the process of low temperature oxidation.

\section{SUMMARY}

1. A high degree of hydrothermal circulation does not always result in oxidation of titanomagnetites in basalts. Oxidation of titanomagnetites at low temperatures in relatively young crust depends mainly on grain size or on the microstructure surrounding the mineral, i.e., porosity or cracks in the rock.

2. Although the titanomagnetite of most submarine basalts exhibits a very limited range of titanium content $(x \approx 0.60)$, some differences were observed in the sam- 

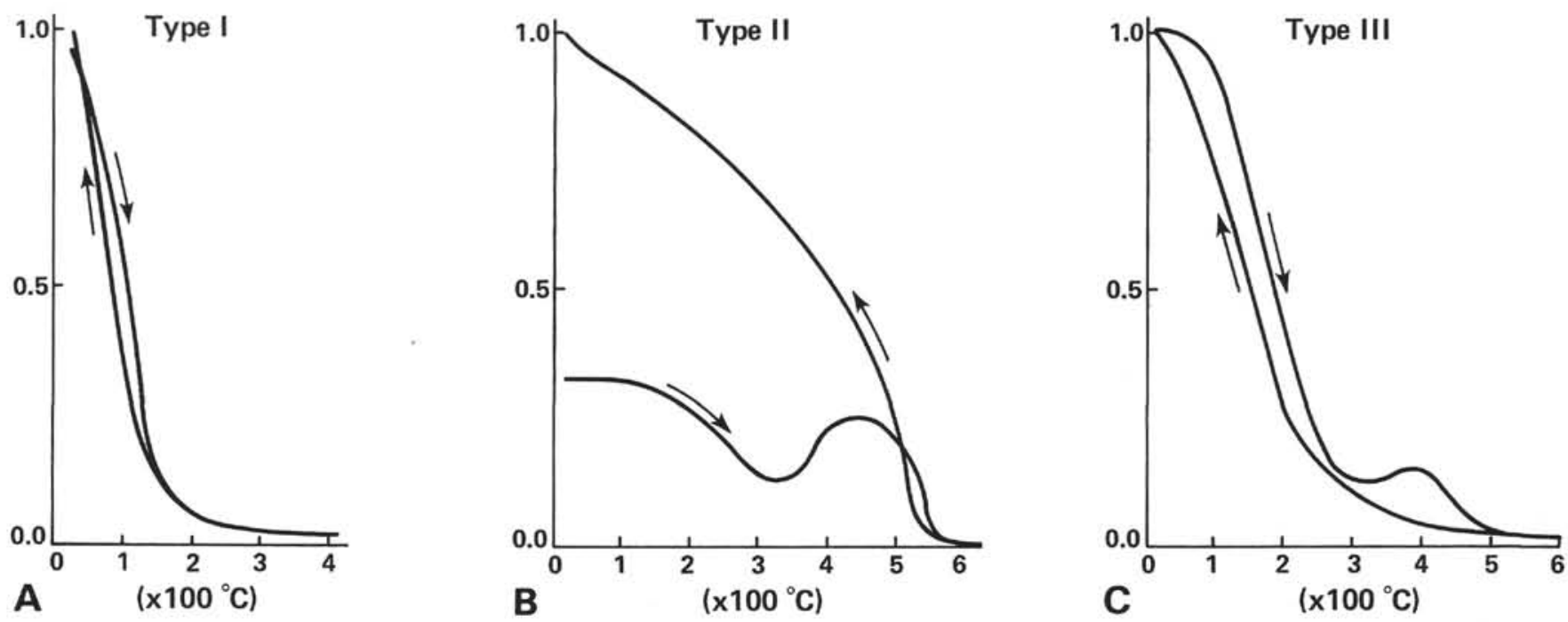

Figure 2. Main types of thermomagnetic curves. A. Type I, nearly thermally reversible (e.g., Sample 507B-1-1, 18-20 cm). B. Type II, typical irreversible curve observed with basalts oxidized at low temperature (e.g., Sample 510-11-1, 18-21 cm). C. Type III, thermally irreversible with low $T_{c h}$ (e.g., Sample 510-10-1, 26-28 cm).

ples examined. The $\mathrm{x}$-values of unoxidized titanomagnetites from Hole 507B basalts are larger than 0.6.

3. An increase in Curie temperature with increase in crustal age was observed. This was true too of basalts from the FAMOUS area (Johnson and Atwater, 1977). The increase in Curie temperature was attributed to progressive oxidization at low temperature.

\section{ACKNOWLEDGMENTS}

The author would like to acknowledge the able assistance of the shipboard scientific and technical staff on DSDP Leg 70 . The manuscript was read and critically reviewed by K. Momose, M. Funaki, S. Tonouchi, and S. Levi.

\section{REFERENCES}

Anderson, R. N., Clague, D. A., Klitgord, K. D., Marshall, M., and Nishimori, R. K., 1975. Magnetic and petrologic variations along the Galapagos Spreading Center and their relation to the Galapagos melting anomaly. Geol. Soc. Am. Bull., 86:683-694.

Day, R., Fuller, M., and Shmidt, V. A., 1977. Hysteresis properties of titanomagnetites: Grain-size and compositional dependence. Phys. Earth Planet. Int., 13:260-267.

Furuta, T., in press. Magnetic properties of basalt samples of Hole 504B and 505B on the Costa Rica Rift, DSDP Leg 69 and Leg 70. In Cann, J. R., Langseth, M. G., Honnorez, J., Von Herzen, R. P., White, S. M., et al., Init. Repts. DSDP, 69: Washington D.C. (U.S. Govt. Printing Office).
Hekinian, R., Fodor, R. V., Goll, R. M., Hoffert, M., Humphris, S. E., Mattey, D. P., Natland, J., Petersen, N., Roggenthen, W., Schrader, E. L., Srivastava, R. K., and Warren, N., 1978. Hydrothermal deposits and associated basement rocks from the Galapagos Spreading Center. Oceanol. Acta, 1:473-482.

Johnson, H. P., and Atwater, T., 1977. Magnetic study of basalts from the Mid-Atlantic Ridge, lat. $37^{\circ} \mathrm{N}$. Geol. Soc. Am. Bull., 88: 637-647.

Johnson, H. P., and Hall, J. M., 1978. A detailed rock magnetic and opaque mineralogy study of the basalts from the Nazca Plate. Geophys. J. R. Astron. Soc., 52:45-64.

Langseth, M. G., and Hobart, in press. Basalts of geophysical site surveys in the Costa Rica Rift. In Cann, J. R., Langseth, M. G., Honnorez, J., Von Herzen, R. P., White, S. M., et al., Init. Repts. DSDP, 69: Washington (U.S. Govt. Printing Office).

Marsh, N., and Tarney, J., in press. Major and trace element geochemistry of basalts, Site 504. In Cann, J. R., Langseth, M. G., Honnorez, J., Von Herzen, R. P., White, S. M., et al., Init. Repts. $D S D P, 69$ : Washington (U.S. Govt. Printing Office).

Petersen, N., and Roggenthen, W. M., 1980. Rock and paleomagnetism of DSDP Leg 54 basalts-East Pacific Rise and Galapagos Rift. In Rosendahl, B. R., Hekinian, R., et al., Init. Repts. DSDP, 54: Washington (U.S. Govt. Printing Office), 865-876.

Ryall, P. J. C., and Hall, J. M., 1980. Iron loss in titanomagnetites during low temperature oxidation. J. Geomagn. Geoelectr., 32: 661-669.

Vogt, P. R., and Johnson, G. L,.., 1973. Marine telechemistry. Nature, 254:373. 
Table 2. Thermomagnetic properties and titanomagnetic compositions of basalts recovered from Holes 506G, 507B, C, 508B, and 510 .

\begin{tabular}{|c|c|c|c|c|c|c|}
\hline $\begin{array}{c}\text { Sample } \\
\text { (interval in } \mathrm{cm} \text { ) }\end{array}$ & $T_{c 1}^{\mathrm{a}}$ & $T_{c 2^{b}} \mathrm{~b}$ & $T_{c h}{ }^{\mathrm{c}}$ & $J_{h} / J_{0} \mathrm{~d}$ & Type $^{\mathrm{e}}$ & $x$-Value $f$ \\
\hline \multicolumn{7}{|l|}{ Hole 506G } \\
\hline $\begin{array}{l}2-1,9-11 \\
2-1,75-77 \\
2-1,86-88 \\
2-1,122-124\end{array}$ & $\begin{array}{l}140 \\
185 \\
130 \\
180\end{array}$ & $\begin{array}{l}\overline{425} \\
\overline{450}\end{array}$ & $\begin{array}{l}140 \\
255 \\
150 \\
275\end{array}$ & $\begin{array}{l}1.0 \\
1.3 \\
1.1 \\
1.4\end{array}$ & $\begin{array}{c}1 \\
\text { (II) } \\
1 \\
\text { (II) }\end{array}$ & $0.614 \pm 0.026(10)$ \\
\hline \multicolumn{7}{|l|}{ Hole 507B } \\
\hline $\begin{array}{l}1-1,18-20 \\
1-1,20-22 \\
1-1,40-42 \\
1-1,42-44 \\
1-1,57-59\end{array}$ & $\begin{array}{l}140 \\
190 \\
145 \\
180 \\
150\end{array}$ & $\begin{array}{l}- \\
\bar{?} \\
-\end{array}$ & $\begin{array}{l}140 \\
225 \\
200 \\
375 \\
210\end{array}$ & $\begin{array}{l}1.0 \\
1.1 \\
1.3 \\
1.5 \\
1.3\end{array}$ & $\begin{array}{c}1 \\
1 \\
1 \\
\text { II } \\
\text { I }\end{array}$ & $\begin{array}{l}0.663 \pm 0.021(20) \\
0.711 \pm 0.031(25) \\
0.706 \pm 0.018(21) \\
0.650 \pm 0.019(20)\end{array}$ \\
\hline
\end{tabular}

Hole 507C

$\begin{array}{llllll}\mathrm{B} 1-1,5-7 & 200 & 455 & 320 & 1.6 & \text { (II) }\end{array}$

Hole 508B

$3-1,11-13$

$3-1,42-44$

4-1, 3-5

$\begin{array}{llll}190 & 450 & 405 & 1.9 \\ 160 & - & 220\end{array}$

$260-260$

Hole 510

8-2, 100-102

$8-2,116-11$

$9-1,31-33$

$9-1,56-58$

$9-1,82-84$

9-2, 6-8

$9-2,133-134$

$9-3,16-18$

$9-3,26-28$

$9-3,34-36$

$10-1,12-14$

$10-1,26-28$

$11-1,18-21$

$11-1,96-100$

$\begin{array}{llll}300 & 470 & 395 & 1.2 \\ 260 & - & 270 & 1.0 \\ 230 & - & 205 & 0.9 \\ 260 & - & 250 & 1.0 \\ 300 & - & 275 & 0.9 \\ 265 & - & 230 & 0.9 \\ 290 & 560 & 540 & 1.4 \\ 300 & 550 & 535 & 2.0 \\ 300 & 520 & 525 & 1.7 \\ 240 & - & 205 & 0.9 \\ 245 & - & 225 & 1.0 \\ 265 & 480 & 240 & 1.0 \\ 300 & 555 & 540 & 3.1 \\ 260 & 520 & 520 & 1.7\end{array}$

II)

$0.594 \pm 0.031(17)$

$0.452 \pm 0.130(26)$

a The first Curie temperatures $\left({ }^{\circ} \mathrm{C}\right)$ observed during heating.

b The highest Curie temperatures $\left({ }^{\circ} \mathrm{C}\right)$ observed during heating.

c The second Curie temperatures $\left({ }^{\circ} \mathrm{C}\right)$ observed during cooling.

d The ratio of saturation magnetization observed at room temperature after and

before heating.

e Thermomagnetic curves explained in the text; parentheses denote atypical

curve.

Value of the formula $x \mathrm{Fe}_{2} \mathrm{TiO}_{4} \cdot(\mathrm{I}-\mathrm{x}) \mathrm{Fe}_{3} \mathrm{O}_{4}$; uncertainty is one standard deviation; the number in parentheses is the number of grains of titanomagnetite analyzed.

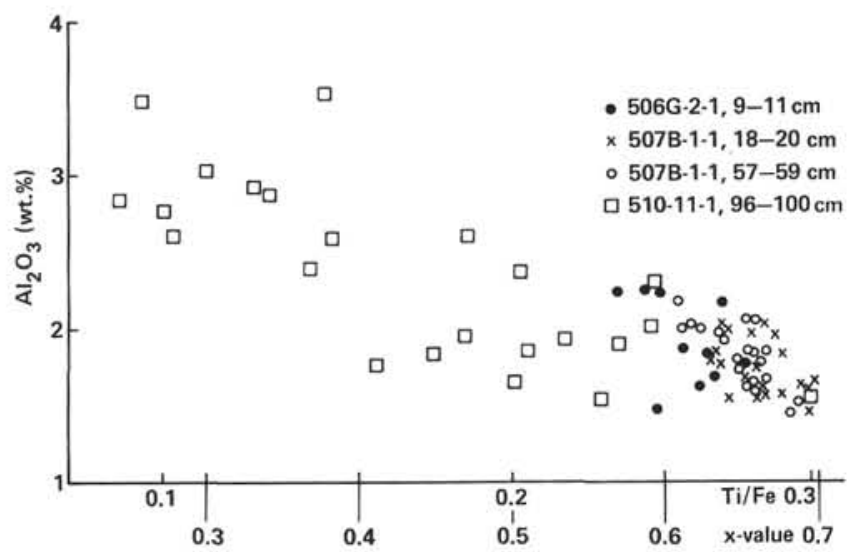

Figure 3. Variation of $\mathrm{x}$-values (or $\mathrm{Ti} / \mathrm{Fe}$ ratios) with $\mathrm{Al}_{2} \mathrm{O}_{3}$ content of titanomagnetites.

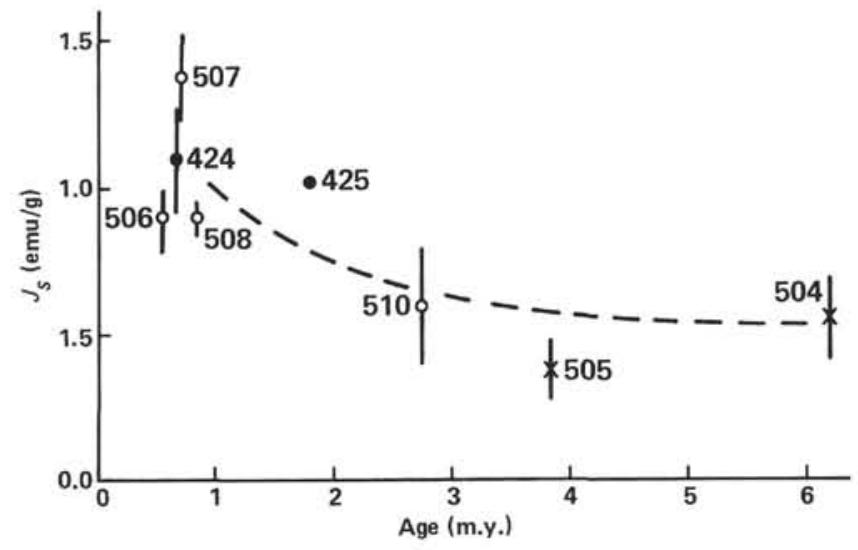

Figure 4. Saturation magnetization $\left(J_{s}\right)$ as a function of crustal age. Sites 504 and 505 are at the Costa Rica Rift; Sites 506, 507, 508, and 510 are at the Galapagos Rift. (Data for Sites 424 and 425 are from Petersen and Roggenthen [1980].)

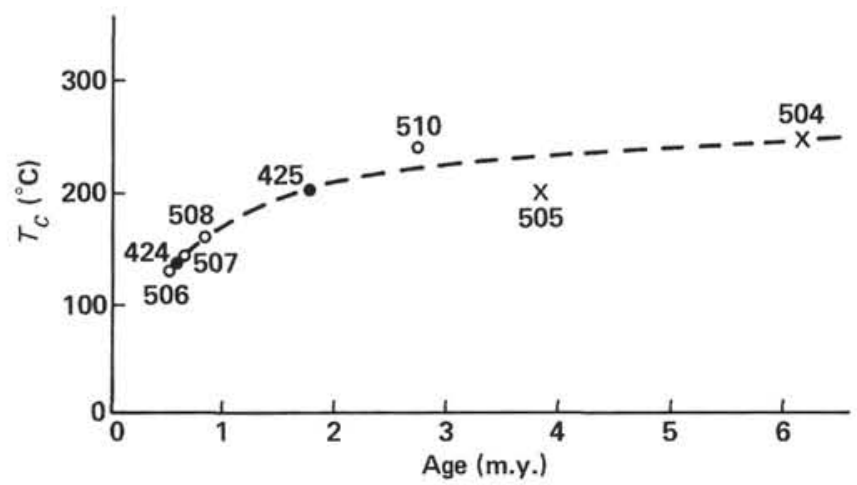

Figure 5. Curie temperature $\left(T_{c}\right)$ as a function of crustal age. Sites 504 and 505 are at the Costa Rica Rift; Sites 506, 507, 508, and 510 are at the Galapagos Rift. (Data for Sites 424 and 425 are from Petersen and Roggenthen [1980].) 